This is a postprint version of the following published document:

Santiago-Caballero, C. (2013). Trapped by nature: provincial grain yields in Spain in the mid 18th century. Revista de Historia Económica - Journal of Iberian and Latin American Economic History, v. 31, n. 3, pp. 359-386. Available in: http://dx.doi.org/10.1017/S0212610913000165

(C) Cambridge University Press 


\title{
TRAPPED BY NATURE: PROVINCIAL GRAIN YIELDS IN SPAIN IN THE MID $18^{\text {TH }}$ CENTURY*
}

\author{
CARLOS SANTIAGO-CABALLERO
}

Universidad Carlos III de Madrid ${ }^{\text {a }}$

\begin{abstract}
This paper estimates original yields for five grains in thirty-three provinces of Spain in the mid- $18^{\text {th }}$ century. We observe a strong heterogeneity between the provinces with yields being considerably higher in the north of the country than in the south-east. Although average yields in Spain were below those in other countries of north-western Europe, the provinces in the north achieved yields not far behind the most advanced agricultural regions of the world. The heterogeneity of yields across Spain can be explained by the different climatic conditions in each province. Although all the provinces improved their yields in the long term, the differences between the provinces remained stable until the modernisation of Spanish agriculture around the mid- $20^{\text {th }}$ century.
\end{abstract}

Keywords: grain yields, agriculture, climate

JEL Code: N34, N54

* The author is grateful to the members of the department of Economic History and Institutions at Universidad Carlos III, two anonymous referees for their useful comments, and the editor for her suggestions. Financial support from the Spanish Ministerio de Economía y Competitividad project «Bienestar y desigualdad en una sociedad preindustrial: España, 1500-1800» ECO201238028 is acknowledged.

a Departamento de Ciencias Sociales. Calle Madrid, 126. Getafe, CP 28903, Madrid, Spain. carlos.santiago@uc3m.es. 


\section{RESUMEN}

Este artículo realiza nuevas estimaciones de rendimientos de cinco cereales 33 provincias españolas a mediados del siglo XVIII. Nuestros resultados indican una gran heterogeneidad entre las provincias analizadas y que los rendimientos eran considerablemente más altos en el norte del país que en las provincias del sureste. Aunque los rendimientos medios en España se encontraban por debajo de Europa noroccidental, las provincias del norte fueron capaces de alcanzar rendimientos cercanos a las regiones agrarias más avanzadas del mundo. La heterogeneidad provincial puede ser explicada por las los factores climaticos dominantes en cada provincia. Aunque todas las provincias mejoraron sus rendimientos en el largo plazo, las diferencias se mantuvieron hasta la modernización de la agricultura española a mediados del siglo XX.

Palabras Clave: rendimientos, agricultura, cereales, clima

\section{INTRODUCTION}

On the eve of the industrial revolution, grain yields in England had grown to unprecedented levels ${ }^{1}$. The long-term changes that took place in rural England during the $17^{\text {th }}$ and $18^{\text {th }}$ centuries have been considered by many as one of the cornerstones of the development of the English economy ${ }^{2}$. This was not the case for Spanish agriculture and, in fact, in the Iberian case, low productivity levels in agriculture have traditionally been considered as one of the main reasons behind the lack of economic development ${ }^{3}$. Although there were slow improvements in the $19^{\text {th }}$ century, it was not until the mid- $20^{\text {th }}$ century that Spain carried out substantial changes in farming techniques to overcome her environmental disadvantages ${ }^{4}$.

Grains were by far the most important crop in Spanish agriculture. It was estimated that, in Castile, more that 80 per cent of the land was typically

1 Allen (1988), Clark (1991).

2 Allen argued that raising agricultural productivity was both a consequence of the development of a high-wage economy and a cause of economic growth, freeing labour that could be used in urban areas (Allen 2003, 2004). In Spain Prados de la Escosura (1988) and Clar and Pinilla (2009) also explain the connection between agrarian development and economic growth.

${ }^{3}$ This argument was used repeatedly in the literature by authors such as Nadal (1984) while others, such as Fraile (1991), argued that low agricultural productivity was not the major cause behind Spanish underdevelopment.

${ }^{4}$ Simpson (1997). During the $19^{\text {th }}$ century there were some significant improvements in the north, although the changes in the rest of the country were slowed down by negative natural endowments (Gonzalez de Molina 2001). Some regions such as the Ebro valley carried out significant improvements in the production of cereals, while most of the country still suffered the restrictions of an organic agriculture (Gallego 2001, p. 191). 
dedicated to the cultivation of cereals (Llopis 2002, p. 128). Wheat yields in Spain almost doubled during the second half of the $19^{\text {th }}$ century, increasing from around 5 quintals/quintals/ha in the mid- $19^{\text {th }}$ century to nearly 10 in the first decade of the $20^{\text {th }}$ century ${ }^{5}$. Yields then remained stable until the modernisation of the Spanish economy, which began in the 1960s (INE 1920 2008). However, the study and use of national averages can hide the existence of important regional patterns. The regional dimension of this paper will allow us to analyse land productivity in more depth and to give a more precise explanation of its sources. If, as some authors argued, agricultural productivity was crucial for economic development, its estimation and study in Spain is also essential in order to understand her economic history.

O'Brien and Prados de la Escosura presented Spain as a country where agricultural productivity remained well below most of her European counterparts. This was not only the case in terms of land productivity, but also when labour productivity was taken into account (O'Brien and Prados de la Escosura 1992, p. 531). The debate concerning the low agricultural productivity levels in Spain has offered several possible explanations, with unfavourable natural conditions often cited as the most important one. In fact, authors such as O'Brien and Keyder (1978) suggested that natural conditions played an important role in the advantage enjoyed by countries like England. Economic historians such as Llopis (2002, p. 127) explained the significant natural handicap faced by Spanish agrarian producers. Tortella (1994, p. 5) showed that the dry weather, altitude and high transport costs of the interior acted as brakes for innovation in the Spanish countryside. The lack of efficient transport systems did not allow the rise of a marketoriented agriculture but led instead to self sufficiency and local isolationism (Ringrose 1983, p. 164). The problem was not just based on the direct effects of nature, but also on the obstacles that the Spanish climate and landscape put in the way of the possible adoption of new techniques that had been successfully applied to the agricultures in north-western Europe. Authors such as Garrabou Segura (1993, p. 95) and Gonzalez de Molina (2001, p. 63) argue that the lack of rain was an insuperable obstacle as the cultivation of legumes, key in the success of the English agrarian revolution, required amounts of water only available in irrigated lands in most parts of Spain. The dry climate also meant less pasture land and therefore the possibilities to maintain livestock that could provide manure to improve yields were lower than in other countries of Europe (Gonzalez de Molina 2001, p. 57). Recent works reveal that the role of climate and geography in Spain went beyond the effects in agriculture. Dobado Gonzalez explains that the economic future of many Spanish provinces was already largely determined at the end of the Ancient Regime by the influence of natural variables such as proximity to the

5 Tortella (2003), although some authors, such as Simpson (1997), are reluctant to accept the increase. 
coast or rain (Dobado Gonzalez 2004, p. 111). In a similar way, Ayuda et al. (2010) show that rainfall and altitude are significant variables explaining the spatial distribution of the Spanish population, although they also conclude that this effect weakened as the country modernised.

This paper will add new information to the debate on Spanish agricultural productivity by analyzing the geographical distribution of yields for the five main crops cultivated in Spain. Using a source well known to economic historians the Catastro de la Ensenada we created a new dataset for the 33 modern provinces included in the former Crown of Castile. By following the methodology used by other authors to estimate grain yields around Europe, our results will be internationally comparable and will add valuable new information to the European debate on agrarian development on the eve of the industrial revolution. The aggregation in modern provincial boundaries will also allow us to study whether the provincial differentiation within Spain changed over time and the exact moment when the traditional structures were broken. Therefore, the main contribution of the paper is twofold; first, we estimate and provide a new dataset for the yields of five grains in 33 provinces for the mid- $18^{\text {th }}$ century, which is compared with other datasets from around the world. Second, the aggregation of the results in modern provincial boundaries will provide information that can also be compared with more recent estimations of yields. This will allow researchers to understand not just the aggregated evolution of Spanish agriculture in the long run, but also to enrich the existing literature on regional development by shedding some light on the evolution of agricultural productivity at provincial level.

The first part of the paper offers a brief geographical and climatic description of Spain; this is necessary to understand and put into context the results that will be presented in the following sections. The second part of the study presents the sources and the methodology employed to estimate the grain yields of the 33 provinces of the Crown of Castile during the early 1750s. The Crown of Castile was the main political entity of Spain and represented around 80 per cent of her territory. The third part of the paper introduces the yields of the five main crops produced in Spain: wheat, barley, rye, oats and maize, estimated from original archival sources. The results reveal substantial differences that were especially intense between the southeast and the north. We then compare the results obtained for Spain in the mid- $18^{\text {th }}$ century with yields in other countries. We conclude that, although the national Spanish average was below other international standards, yields in the north of the country were not far behind the most productive regions of the world. We subsequently compare the differences in yields between the provinces in the mid- $18^{\text {th }}$ century with the information from the $20^{\text {th }}$ century to identify the exact moment when low-yield provinces were able, finally, to break their natural limitations and catch up with high-yield regions. Finally, we offer some explanations for the heterogeneity of grain yields across 
the provinces, suggesting that climatic and natural conditions were the main relevant factors.

\section{SOURCES AND METHODOLOGY}

Tithe records have traditionally been the most important source of information for the estimation of grain production. From Old English teotha (tenth), tithes represented a flat tax of 10 per cent paid every year by producers in the primary sector to the church. This charge was made on all products, from the main ones such as grain, wool, wine or olive oil to minor products such as cheese, honey or chicken. In Spain, the payment of the tithe was compulsory until the «Desamortizacion of Mendizabal» in 1837 when the government confiscated ecclesiastical lands and theoretically released producers from the payment of the tithe. Tithes are therefore an excellent source to estimate the evolution of agrarian production until the early $19^{\text {th }}$ century when their reliability decreased significantly with the economic and social turmoil produced by the Napoleonic wars ${ }^{6}$. However, tithe records only mentioned the amount of each product but did not explain how much land had been used to produce it. Therefore, they cannot be used to estimate yields unless we assume that the percentages of land put under cultivation remained constant, an assumption that is clearly unreasonable.

For this reason, the main source used in this paper is the Catastro de la Ensenada, a general survey that took place in Castile in the early 1750s and which contains enough information to estimate grain yields. In the mid- $18^{\text {th }}$ century, King Ferdinand VI and his government tried to modernise the fiscal system in Castile with the introduction of a general tax. In order to calculate the amount to be paid by each municipality, he ordered the elaboration of a survey known as the Catastro de la Ensenada to be completed by all municipalities in Castile. All the municipalities had to create a committee that responded to several questions including social and economic aspects of the place and its inhabitants. The level of information included in the Catastro is so high that it is considered the most detailed survey ever conducted in Spain.

Among other considerations, the information was divided between «particular» and "general» answers. Particular answers were the most detailed records and studied the situation of every family in every village. Each family had to present information about its members including ages, names, jobs, incomes, properties, debts or credits, and a long list of further requirements. The general questions were gathered in a similar way to the

\footnotetext{
${ }^{6}$ Garcia Sanz (1982) and Anes (1978). See Goy and Ladurie (1982) for a compilation of several works. Other examples include Ponsot (1986), Lopez-Salazar Perez and Martin Galan (1981) or Santiago-Caballero (forthcoming). Tithes have also been used to estimate inequality between grain producers (Santiago-Caballero 2011, 2013).
} 
Domesday Book, where the officers visiting every municipality in Castile interviewed a group of representatives. If the information contained in the works of Arthur Young has been extensively used to estimate grain yields in England, Ireland or France, the level of detail achieved in the Catastro provides a monumental dataset for the accurate estimation of Spanish figures. The resources dedicated to the survey matched the ambition of the government that used the work of around 1,000 judges, 6,000 men and 90,000 local experts who measured and studied every single piece of land in more than 14,000 municipalities spending over 40 million reales.

Given its richness, the Catastro has been extensively used by economic historians to study Spanish agriculture in the modern age. As early as 1947, Matilla Tascon compiled a monumental work in which he gathered information at regional level from the labour market to land distribution or the amount of livestock (Matilla Tascon 1947). Vilar (1966) also saw in the Catastro a unique source to understand the economic and social structure of Castile in the mid- $18^{\text {th }}$ century, setting an example that was also followed by other studies such as the attempt of the Grupo '75 (1977) to measure the level of income per capita in Castile. Agrarian historians were quickly seduced by the colossal amounts of information in the Catastro concerning the structure and performance of the Castilian agrarian system. Most of the agrarian studies that used the Catastro as their main source have a local or regional scope, such as Donezar (1984) for Toledo, Garcia Sanz (1986) for Segovia, Mula Gomez and Gris Martinez (1998) for Lorca, Pezzi Cristobal (1997) for Velez-Malaga or Lanza Garcia (2008) for Cantabria ${ }^{7}$.

In our case we use information from the "general» answers, which include a list of forty questions asked by the royal officials to the local authorities. We used the answers given to questions 9, 10 and 12 in the survey to estimate grain yields in each location. The answer to question 10 requested information about the amount of land used for each main agricultural product, as well as the quality of the soil. The answer to question 12 described the average yield of the grains produced in each type of land depending on its quality ${ }^{8}$. One of the most challenging problems of the source is that the unit of measurement changed drastically depending on the region where the municipality was located. In general, most of the provinces in Castile, especially in the centre and south, used fanegas as a unit of dry volume and unit of area. However, sometimes there were changes in the units even within the same province. For example, in the province of

\footnotetext{
7 For a good description of the Catastro, see Camarero Bullon (2002). For other examples of case studies and the use of the Catastro to measure the agrarian sector, see De la Torre Briceño (1992) for Alcala de Henares, Calvo Alonso (1999), Bejarano Rubio and San Feliciano Lopez (1999) for Salamanca or Muñoz Navarro (2010) for Requena.

8 The Catastro normally distinguished between three types of land: first quality (the best), second quality (medium) and third quality (the lowest). The output produced by each type of land in the municipality was reported to the national authorities.
} 
Madrid one fanega of land in the village of Getafe contained $3,441 \mathrm{~m}^{2}$, while in Cenicientos, also located in Madrid, the same fanega contained $5,161 \mathrm{~m}^{2}$. To complicate matters further, the village of Chinchon, also in Madrid, did not use the fanega but the obrada, a unit that contained $1,404 \mathrm{~m}^{2} .{ }^{9}$ To deal with this problem, we used the information provided in question 9 of the Catastro, which describes the different units used in the village and their corresponding value in Castilian bars ${ }^{10}$. In terms of volume, there was also a wide variety of units that changed depending on the region. In the north, especially in Galicia, the ferrado was used instead of the fanega. As in the case of volume units, the same unit could have different values in different locations. With the information contained in this question, we transformed capacity units to quintals and surface units to hectares (ha). The standardised yields that we present in this paper for the thirty-three provinces were therefore calculated in quintals per hectare.

From the many different ways of quantifying grain yields, we decided to use the estimation of the gross yield, or in other words the production of wheat that could be obtained from a particular unit of land. The problem with this sort of calculation is that we do not take other variables such as the share of fallow and the periodicity in which the land was cultivated into account. However, given that this measure is the most common way to measure land productivity in the existing literature, we decided to use it in order to make our results comparable with other regions of the world (Dejoongh 1999, p. 12).

To generate the provincial averages, we chose a sample of municipalities in each province and calculated the yields for the grains cultivated. The provincial yield was calculated as an average of the sample weighted by the amount of land used in each municipality. The methodology is very similar to the impressive work of Bringas (2000) who, using the Catastro, reconstructed productivity figures for fourteen provinces in Castile. However, this sort of estimation can lead to misleading results, mainly as a consequence of the different uses that could be given to land in each region. Let us assume that, in a specific province, the most fertile land is used to produce fruit and the cultivation of grain is relegated to the worst soils. In this case, the grain yields obtained in the province would underestimate the potential yields that could have been achieved if grain had been cultivated in all the types of land as in the rest of the country. We decided to check whether this was a relevant factor in our estimations by comparing our averages with the yields obtained in each province using only the best lands defined in the registries as top quality. The results indicate that the provincial differences of both estimations were practically identical and, therefore, that our average yields are

9 The appendix includes examples of the different units used in different provinces and their values in square metres.

10 The Castilian bar was a standardised measurement representing $0.838 \mathrm{~m}$. 
FIGURE 1

THIRTY THREE PROVINCES IN THE CROWN OF CASTILE

(MODERN BOUNDARIES)

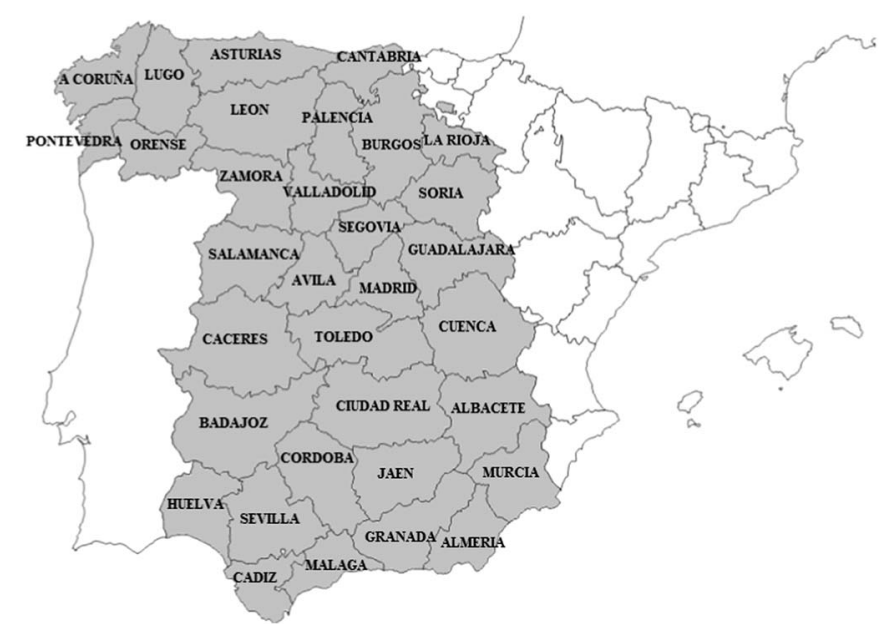

also a good estimation of the potential yields that could be reaped in each province $^{11}$.

Given the complexity of the administrative boundaries of the provinces in $18^{\text {th }}$ century Spain, we chose the modern limits to aggregate the samples (Figure 1) ${ }^{12}$. This exercise will also allow us to compare the productivities obtained for the $18^{\text {th }}$ century with the values in the $20^{\text {th }}$ and $21^{\text {st }}$ centuries when the geographical boundaries use the modern provinces. The sample, comprising 400 municipalities from thirty-three provinces, is geographically spread within each region, and includes a wide variety of locations from large towns to very small villages ${ }^{13}$. In terms of geographical coverage, the sample of municipalities represents more than 20 per cent of the territory of the thirty-three provinces.

\section{GEOGRAPHY AND CLIMATE IN SPAIN}

Located in the south-western corner of the European continent, Spain occupies 85 per cent of the Iberian Peninsula. The country has an average altitude of $660 \mathrm{~m}$, being the second highest in Europe surpassed only by

\footnotetext{
11 The correlation between the two estimations was 93 per cent.

12 See map in the appendix with the old provinces and the modern map used in the paper.

13 See appendix for a detailed description of the sample.
} 
FIGURE 2

GEOGRAPHY IN SPAIN

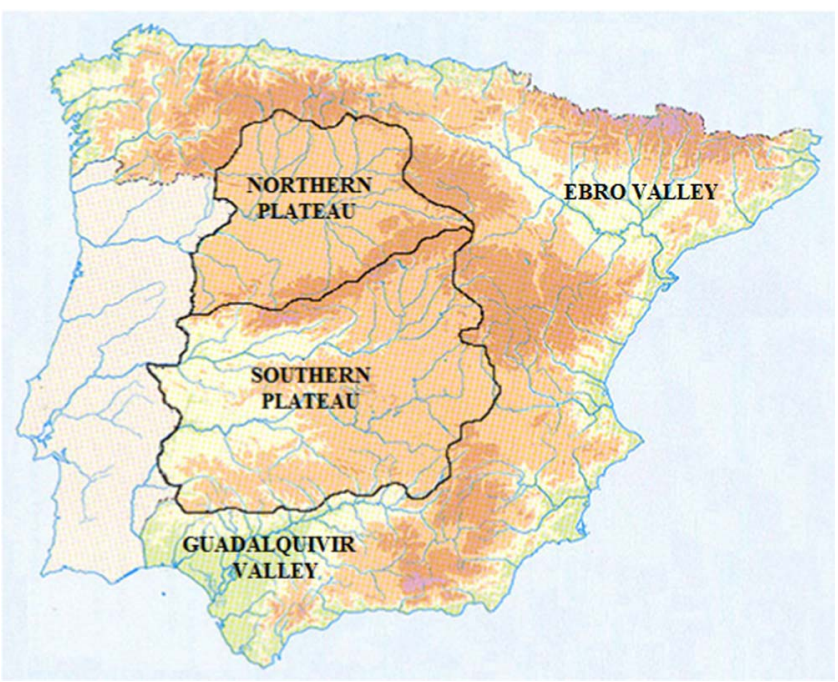

Switzerland. The geography of Spain can be divided into the huge central plateau, coastland areas and the alluvial valleys surrounding the most important peninsular rivers. The plateau is divided into two by the Central System, one of the four main mountain ranges in Spain, separating the northern and southern sub-plateaus. Spanish geography is therefore dominated by the central plateau, an area that occupies $240,000 \mathrm{~km}^{2}$, almost half of the Spanish territory with an average altitude of $650 \mathrm{~m}$. The northern subplateau has an altitude that varies between 650 and $750 \mathrm{~m}$, and comprises the Autonomous Community of Castile and Leon (Old Castile and Leon in the early modern period) and also the Douro basin that crosses the sub-plateau from east to west.

Land fertility depends on numerous factors, including geographical ones such as altitude. Figure 2 presents an altitude map of the Spanish territory and shows the main geographical elements that compose Spain. The two main fluvial valleys, the Ebro in the north-east and the Guadalquivir in the south-east and also the other minor valleys created by the effects of the Tagus and Guadiana rivers in the east. An interesting point to highlight is the considerable altitude of the northern sub-plateau with an average altitude of $750 \mathrm{~m}$, and part of the southern, mainly in its eastern limits where the altitude increases considerably reaching an average of $600 \mathrm{~m}$ in most of the area. In terms of altitude, the worst lands are those around the main mountain chains that surround the central plateau and that occupy a considerable 
proportion of the peninsula. There is also a clear decrease of altitude in the southern sub-plateau from east to west as we approach the Guadiana and Tagus valleys that tend to be more fertile regions. The areas with lower altitudes are located along the coast, in the area surrounding the Ebro valley in the north-east, and especially in the fertile lands of the south-west in the Guadalquivir valley. The territories in the Tagus and Guadiana valleys also have low altitudes. In all cases, altitude is below $500 \mathrm{~m}$ and in cases such as the Guadalquivir valley never even reaches $250 \mathrm{~m}$.

Spain is also a country with a wide range of climatic diversity. The major part of the Spanish territory is under the influence of a Mediterraneancontinental climate, characterised by a very extreme variability (Tortella 2003 , p. 8). Mediterranean climate affects the Mediterranean and southern coasts, while oceanic climate is found along the north coast of the peninsula. The Mediterranean-continental climate is dominant in the interior of the peninsula, and in some parts of the interior of Spain with very high altitude it becomes a mountain climate. This regime is based on extreme temperatures with very cold winters and very hot summers. Although the average thermal amplitude is moderate, the extreme thermal amplitude is very high ${ }^{14}$. Rainfall in the Mediterranean-continental climate is not abundant with an average of $600 \mathrm{~mm} / \mathrm{year}$, with a distribution that is not homogeneous, and sometimes produces torrential rains (Figure 3).

Although the study of temperatures would also be an interesting factor in terms of climatic variability, in Spain rainfall was the most decisive factor in agrarian performance. Figure 4 presents average rainfall levels for all Spanish provinces. We can observe that high rainfalls are mainly located on the Cantabrian coast and also, to a lower extent, in the Guadalquivir valley in the south of the country. On the other hand, the provinces in the south-east of Spain presented rainfall levels that were considerably lower than the regions in the north and that in many cases did not reach $400 \mathrm{~mm} / \mathrm{year}^{15}$.

\section{PROVINCIAL YIELDS}

Figure 5 shows the yields calculated for wheat produced in the thirtythree provinces and a clear geographical pattern can be seen ${ }^{16}$. The results indicate that the four provinces of Galicia in the north-western corner of Spain had the highest wheat yields. Pontevedra, with yields of 9.4 quintals/ ha, leads the ranking followed by A Coruña with 8.7, Lugo with 8.9 and

14 Average thermal amplitude measures the difference between the average maximum and the average minimum of the year. Extreme thermal amplitude measures the same difference but between the maximum and minimum values of the year reached in a certain day; in other words between the hottest and the coldest days of the year.

15 Base de datos INEbase, INE.

16 The average yields for the five main grains cultivated in Spain are presented in the appendix (Table 1). 


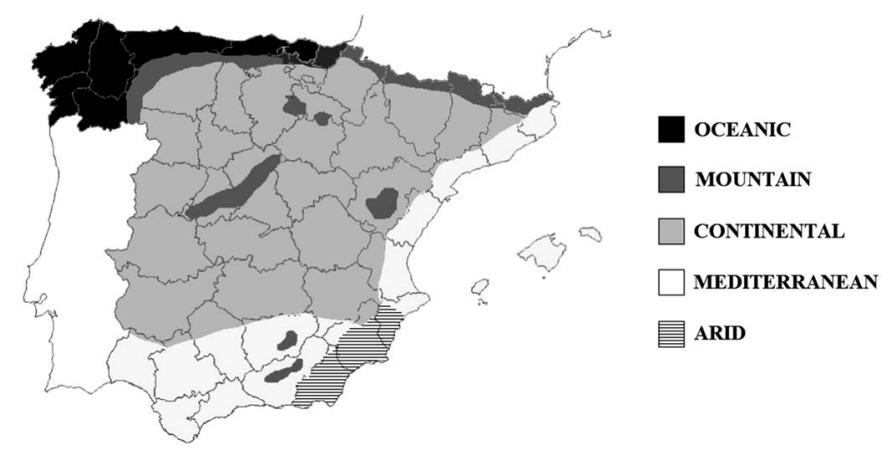

FIGURE 4

RAINFALL LEVELS (MM PER YEAR)
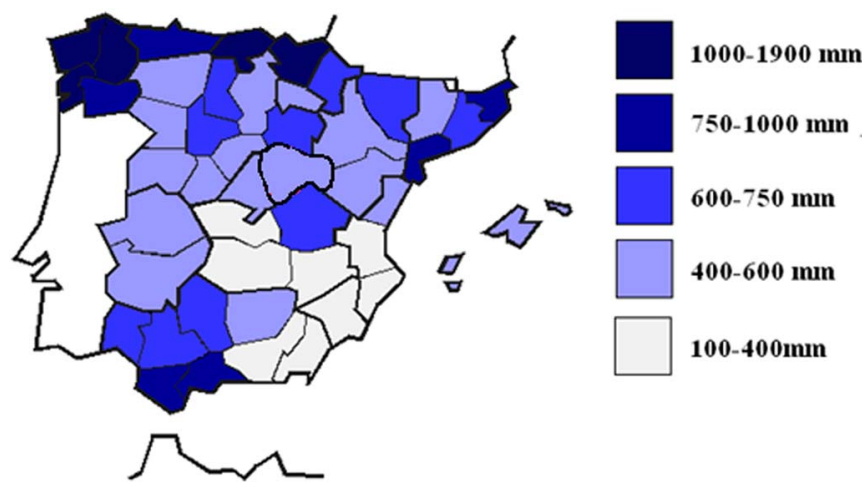

Source: INE (INEBase)

finally Orense, the inland province, with average yields of 8.0 quintals/ha. The other two provinces able to reap yields above 7.0 quintals/ha were Asturias and Cantabria with 7.5 and 7.3 quintals/ha, respectively. The results are not a surprise because, as explained previously, the six northern provinces form the "wet Spain» with an oceanic climate regime characterised by abundant rains. On the other hand, the provinces in the south-east obtained the lowest yields in our estimations. Albacete was the region with the lowest yields with just 2.3 quintals/ha, followed by Almeria and Ciudad Real with 2.7 and 3.3, respectively. The explanations behind the low yields of the south-east can also be related to the arid climate regime dominant in large parts of the 
FIGURE 5

WHEAT YIELDS 1750S (QUINTALS/HA)

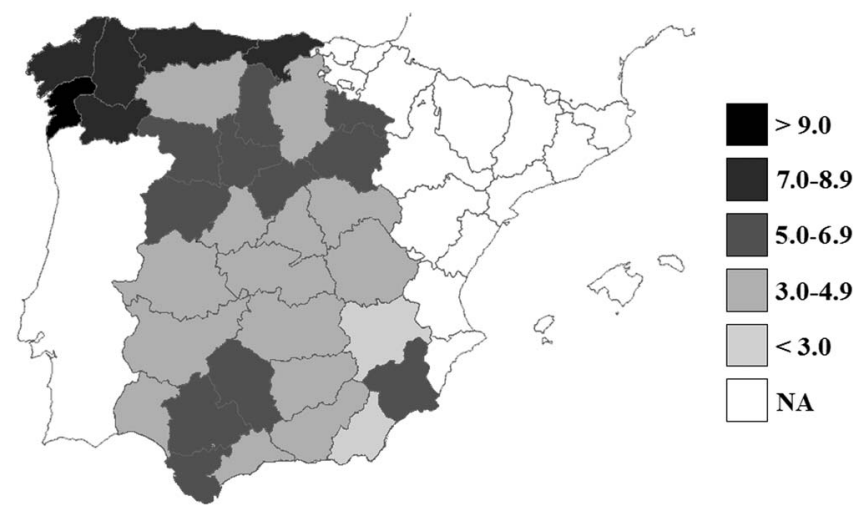

Source: Calculated from the Catastro.

three provinces. In the middle of the distribution, we can also distinguish two groups of provinces. Those provinces located in the fertile lands of the Guadalquivir valley in Andalusia and in the north of Old Castile reaped yields between 4.5 and 6.0 quintals/ha, while the drier provinces of the interior in Extremadura and New Castile did not usually surpass the 4.5 quintals/ha threshold.

Following wheat, barley was the second most important grain in Spain. The analysis of its yields at a provincial level shows similar geographical patterns. Barley was hardly cultivated in the coastal provinces in the north, although it was common in the rest of the country with the highest yields reached in the north of Old Castile. The highest yields were reaped in the provinces of Palencia and Leon with 20.3 and 20 quintals/ha. Salamanca, Zamora and Valladolid complete a cluster in the eastern half of Old Castile. The lowest yields were, as in the case of wheat, located in the south-east and also in the provinces of Caceres and Badajoz with yields below 5 quintals/ha. The vast interior of Castile appears in the middle positions with most of the provinces reaping yields ranging between 7.0 and 10.0 quintals/ha (Figure 6).

Although rye was considered a grain of lower quality, its biological characteristics made it especially popular in the northern provinces. The explanation lies in its biological characteristics, which made its cultivation possible in marginal soils where the growth of wheat and even barley was not a possibility. The six provinces in the north of Castile were the only ones able to reap yields over 6.0 quintals/ha, with Lugo reaching almost 10 quintals/ha. On the other side of the distribution, once more, we find three provinces of the south-east of Castile with Albacete and Granada showing the lowest yields of 2.5 and 
TABLE 1

PROVINCIAL GRAIN YIELDS, 1750S (QUINTALS/HA)

\begin{tabular}{|c|c|c|c|c|c|c|c|c|c|c|c|}
\hline & Wheat & Barley & Rye & Oats & Maize & & Wheat & Barley & Rye & Oats & Maize \\
\hline A Coruna & 8.7 & 12.6 & 6.9 & & 9.8 & Leon & 4.4 & 20.3 & 3.8 & 6.9 & \\
\hline Albacete & 2.3 & 4.1 & 2.5 & 2.5 & & Lugo & 8.9 & & 9.8 & & 9.5 \\
\hline Almeria & 2.7 & 4.0 & 3.0 & & 5.1 & Madrid & 4.2 & 9.9 & 3.6 & 4.0 & \\
\hline Asturias & 7.5 & & 7.9 & 7.1 & 10.8 & Malaga & 3.9 & 5.1 & 5.5 & & 14.9 \\
\hline Avila & 4.4 & 8.9 & 3.9 & & & Murcia & 5.3 & 8.4 & 4.2 & & \\
\hline Badajoz & 4.3 & 3.7 & & & & Orense & 8.0 & & 6.1 & & 9.2 \\
\hline Burgos & 4.8 & 6.2 & 3.5 & 5.1 & & Palencia & 5.9 & 20.0 & 5.2 & 6.0 & \\
\hline Caceres & 3.6 & 4.8 & 4.0 & & & Pontevedra & 9.4 & & 7.2 & & 8.4 \\
\hline Cadiz & 6.3 & 10.1 & & & & Salamanca & 5.2 & 15.3 & 4.1 & & \\
\hline Ciudad Real & 3.3 & 7.1 & 4.4 & 2.9 & & Cantabria & 7.3 & 8.0 & 6.4 & & \\
\hline Cordoba & 5.8 & 7.7 & 3.8 & 3.9 & & Segovia & 5.3 & 10.7 & 3.1 & 5.1 & \\
\hline Cuenca & 1.8 & 5.9 & 1.6 & 2.8 & & Sevilla & 5.1 & 7.8 & & & \\
\hline Granada & 4.8 & 4.6 & 2.8 & 2.4 & 3.0 & Soria & 6.3 & 9.6 & 4.1 & 5.6 & \\
\hline Guadalajara & 3.8 & 7.9 & 3.7 & 5.1 & & Toledo & 3.7 & 9.5 & 4.2 & 5.7 & \\
\hline Huelva & 4.6 & 6.0 & 3.8 & 4.7 & 3.3 & Valladolid & 5.4 & 17.6 & 3.7 & 4.6 & \\
\hline Jaen & 4.7 & 7.1 & 4.8 & 5.6 & & Zamora & 5.2 & 15.3 & 5.4 & & \\
\hline La Rioja & 5.2 & 8.3 & 5.7 & 8.1 & & & & & & & \\
\hline
\end{tabular}

Source: Own calculations from the Catastro de la Ensenada (Catastro) in Portal de Archivos Españoles en Red (PARES). 
FIGURE 6

BARLEY YIELDS 1750S (QUINTALS/HA)
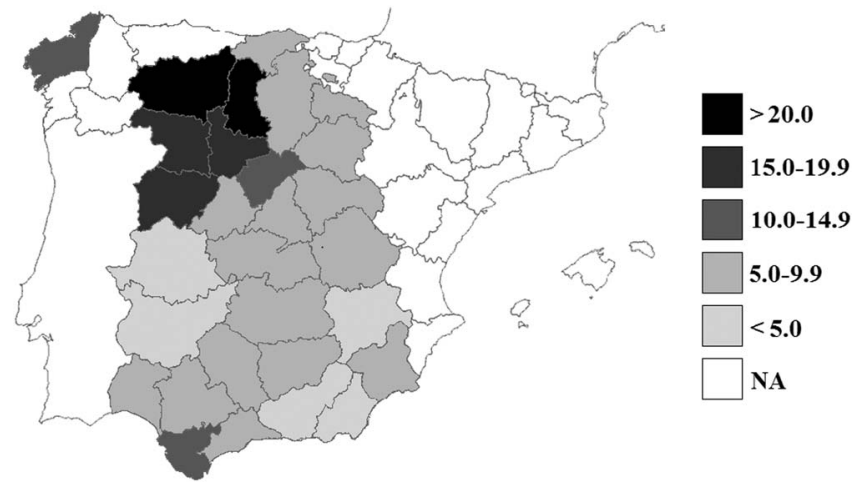

Source: Calculated from the Catastro.

FIGURE 7

RYE YIELDS 1750S (QUINTALS/HA)

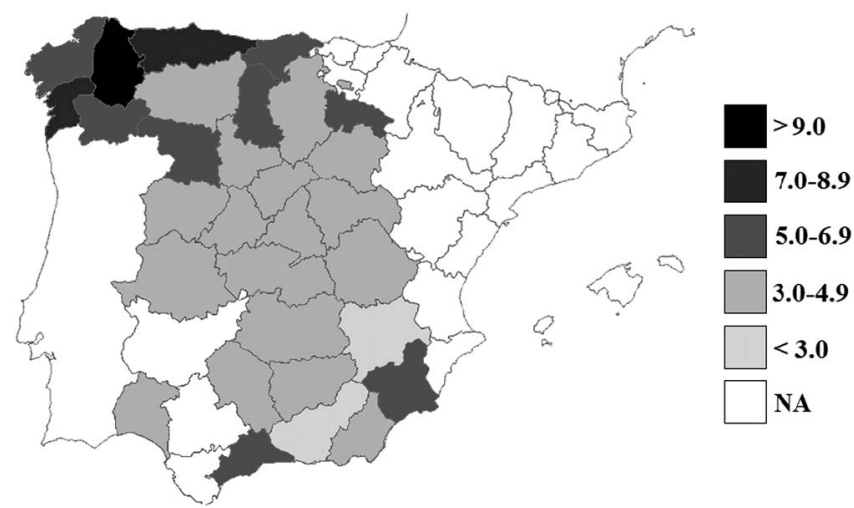

Source: Calculated from the Catastro.

2.8 quintals/ha, respectively, and Almeria following close with just 3.0 quintals/ ha. The yields in the interior of the country did not show significant differences with the exception of the north of Old Castile, with most of the provinces achieving yields ranging between 3.5 and 5.0 quintals/ha (Figure 7).

Of the four main grains grown in Castile, oats occupied the fourth place in importance; a fact that explains why the information we were able to obtain is reduced to a smaller number of provinces. However, and taking into 
FIGURE 8

OATS YIELDS 1750S (QUINTALS/HA)

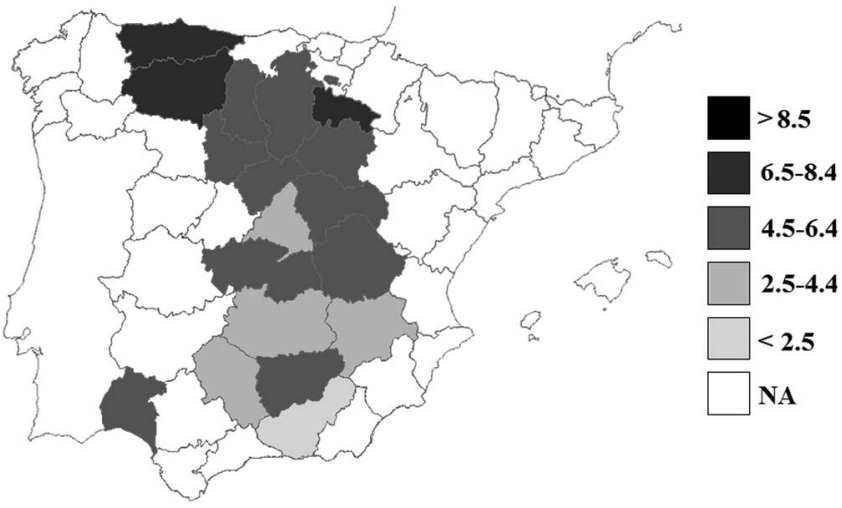

Source: Calculated from the Catastro.

account this limitation, the traditional north/south-east pattern is again clear, with the provinces in the north of Castile being able to reap the highest yields around 7.0 quintals/ha. Granada and Albacete in the south-east presented the lowest yields of 2.4 and 2.5 quintals/ha, respectively. In the rest of the provinces and with few exceptions, yields remained between 4.0 and 6.0 quintals/ha (Figure 8 ).

Maize was, without a doubt, the least common of the five grains included in this study, because only the wet weather of the north suited its cultivation, while producing it without artificial irrigation was not a widespread option in the rest of the country. The production of maize was concentrated in six northern provinces not just for climatic reasons, but also because of the natural characteristics of their soil. Maize is different from the other four crops not simply in that it requires higher amounts of rain, but also because it can be cultivated in marginal lands where none of the other four crops would grow at similar rates. As explained earlier, the mountain ranges that cross the north of Castile create a rough landscape where the cultivation of the traditional grains is not as easy as in the plains of the interior. Therefore, after its introduction from America, the cultivation of maize spread very quickly between the producers of the north. In all six provinces yields were close to 10 quintals/ha with Asturias being close to 11 quintals/ha (Figure 9).

Therefore, we observe a clear pattern with the north-western provinces always reaching the highest yields and those located in the south-east of the country presenting the lowest values; results that match the climatic conditions faced by the different provinces. The case of Murcia appears to be an outlier in the north-west/south-east land productivity pattern. Average wheat 
FIGURE 9

MAIZE YIELDS 1750S (QUINTALS/HA)

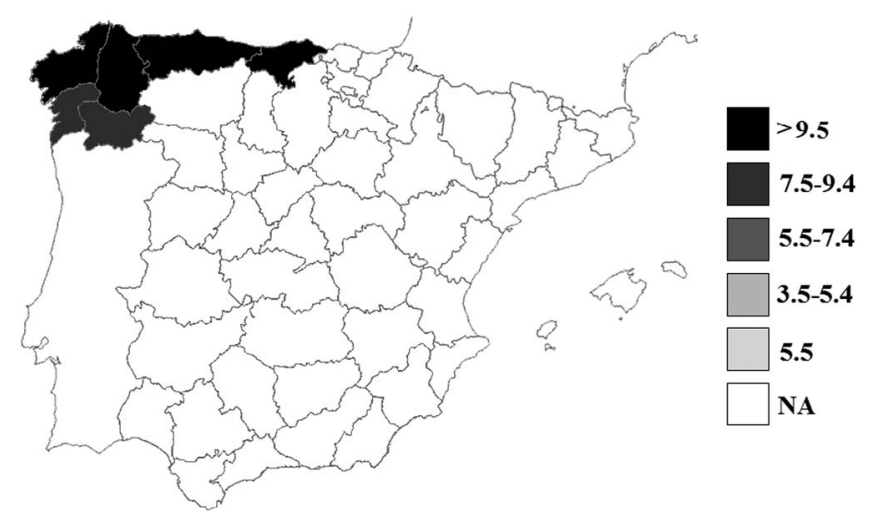

Source: Calculated from the Catastro.

yields were 130 per cent higher in Murcia than in the neighbouring province of Albacete, which had similar rainfall levels. The differences in barley and rye yields were lower but still significant being 105 and 68 per cent higher, respectively, in Murcia. A close inspection of the land cultivated in Murcia reveals that the difference was based on the sort of land used by producers in the province in comparison to neighboring provinces. While in Murcia, good quality land represented 25 per cent of the total area used for grain cultivation, in Albacete the percentage fell to just 3 per cent. In fact, if we compare the yields obtained in land of similar quality in both provinces, we find that the numbers were much closer. In good quality land in Murcia, yields were just 30 per cent higher for wheat, 12 per cent for barley and 19 per cent in the case of rye. We should also take into account that a considerable amount of the land used to produce grain was drained land (Lemeunier 1997, p. 39). Drained lands also made easier the irrigation of the areas around them, as it happened during the first half of the $18^{\text {th }}$ century (NOT CLEAR) (Gonzalez Castaño 2009, p. 214). Although the yields that we present in this study are for dry land and not irrigated, being close to land with a better supply of water could explain slightly higher yields for dry land in Murcia as was also the case in some areas of Toledo (Donezar Diez de Ulzurrun, 1984, p. 217).

\section{COMPARATIVE PERSPECTIVE}

If we estimate the average wheat yields for Spain in the early 1750s, we obtain a result of 4.8 quintals/ha, a value that is similar to the estimation of 
Bringas for the same time ${ }^{17}$. But how good or bad are these results in an international comparative perspective? There are several estimations available for wheat yields in England in the $18^{\text {th }}$ century ranging from 10 quintals/ha in the middle of the century to nearly 15 quintals/ha in the early $19^{\text {th }}$ century (Clark 1991, p. 456). The estimations for other European countries show similar results, with Ireland and Holland probably achieving yields close to England in the early $18^{\text {th }}$ century (Allen and O'Grada 1988, p. 107 and Allen 1992, p. 131). Germany produced 10 quintals/ha in 1800 and the values for northern Europe were close to 9.0 quintals/ha (Chorley 1981, p. 83). Wheat yields in Belgium in 1760 reached on average 9.6 quintals/ha and were very similar to those achieved on average in France around 1800 (Allen and O'Grada 1988, p. 111 and Dejoongh 1999, p. 17). The average grain yields in Spain were much lower than in the rest of north-western Europe and, with 4.8 quintals/ha are, according to Allen, similar to the results that Roman farmers were able to obtain. The average yield in Spain was at the bottom of a «yield ladder» constructed by Hanson, Borlaug and Anderson and represent wheat yield using dry land and traditional techniques (Allen 1992, p. 132). The quality of the land played an important role, and while in countries such as England or France a high proportion of the soil was highly or very highly suitable for the production of rain-fed wheat, in the case of Spain the terrain ranged from simply not suitable to marginally or moderately appropriate (Fischer et al. 2002). However, Allen also suggests that the yields obtained in north-western Europe were exceptional, and that only few exceptions in the rest of the world, such as the Nile basin or the Yangtze delta, reaped similar results with wheat yields around 9.7 quintals/ha (Allen 2009). Outside north-western Europe yields were considerably lower, with values around 7.0 quintals/ha in the early $19^{\text {th }}$ century in areas such as India, Latin America, Canada, Australia or the US (Allen 1992, p. 131). In the mid-18 ${ }^{\text {th }}$ century, rye yields in Russia averaged around 4.0 quintals/ha, a value that was surpassed in most Spanish provinces (Mironov and A'Hearn 2008, p. 918). Therefore, although the differences between Spain and north-western Europe were substantial, the comparison with the rest of the world is less pessimistic (Figure 10).

However, we should also take into account, as explained in the first section of this paper, that Spain is a very heterogeneous country in terms of climate regimes and geographical conditions. This heterogeneity in natural endowments is also reflected in the wide range of wheat yields that we observe at a provincial level. Therefore, although the national average is around 4.8 quintals/ha, the yields in the northern regions were not so far behind the most advanced agrarian regions in the world. The six provinces in the north of Castile averaged 8.4 quintals/ha, and the province of Pontevedra 9.4 quintals/ha. Regional differences were also substantial in other countries such as France, where wheat yields ranged between 5.2 and 14.6 quintals/ha

17 Bringas estimated a productivity of 4.7 quintals/ha in Spain. Bringas (2000). 
FIGURE 10

WHEAT YIELDS AROUND THE WORLD (QUINTALS/A)

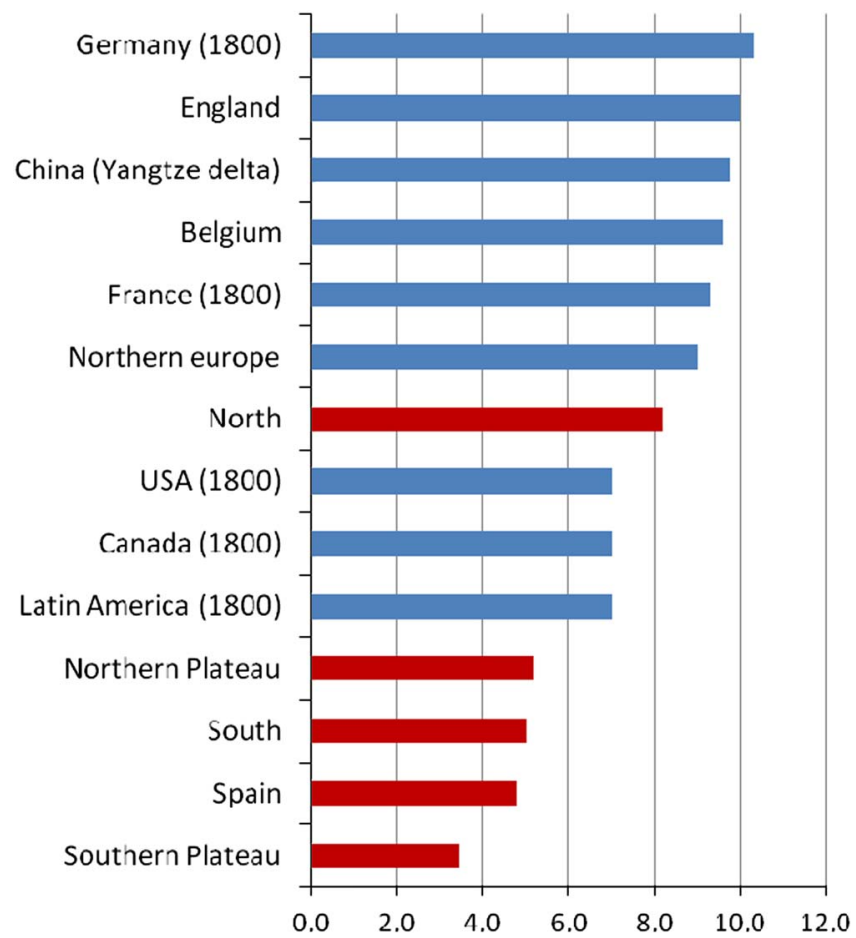

Sources: For Spain Calculated from the Catastro; for England, Clark (1991), Allen (1988), Overton $(1979,1990)$ and Turner (1982); for France, Allen and O'Grada (1988) and Hoffman (1988); for China, Allen (2009); for Belgium Dejoongh (1999); for United States America, Canada and Latin America, Allen (1992); for Germany and northern Europe Chorley (1981).

(Allen and O'Grada 1988, p. 111). Regional variability was also high in Belgium where, in 1760, wheat yields ranged from 5.5 quintals/ha in Luxembourg to 11.6 quintals/ha in Hainaul (Dejoongh 1999, p. 17). Therefore, if we take into account the yields reaped in the most productive provinces of northern Castile, the results indicate that the differences with some of the most efficient grain producers were not so overwhelming. The province of Pontevedra obtained yields similar to the average yields in England or Belgium and also close to those reached in some of the most fertile lands of the world like the Nile basin or the Yangtze delta (Figure 11).

Although it is not the main aim of this paper, taking advantage of the aggregation of data in modern provincial boundaries, we decided to investigate the extent to which the inter-provincial differences in yields that existed in preindustrial times remained, and the moment at which the influence of 


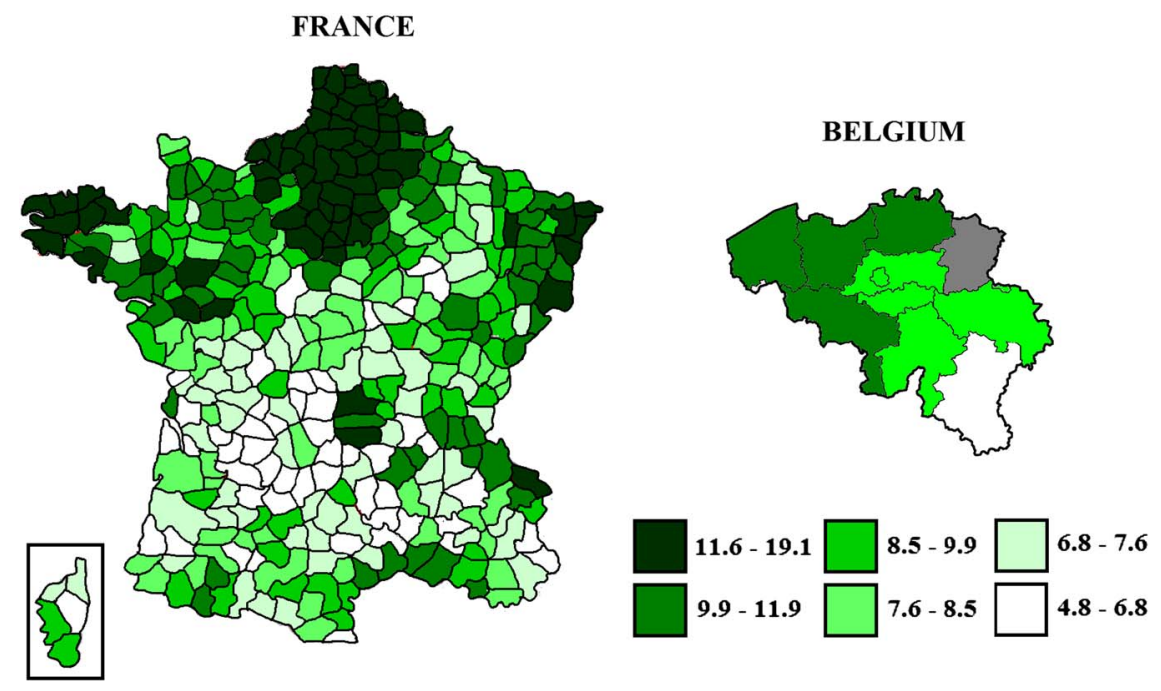

Source: For France, Clout (1980) and for Belgium, Dejoongh (1999).

modernising forces became strong enough to break with the traditional regional differentiation (Simpson 1997, p. 252). Figure 12 shows the correlation coefficient of the yields in the thirty-three provinces by decade between 1920 and 2000 with the yields reaped in the mid- $18^{\text {th }}$ century. Therefore, a high correlation coefficient between the yields in 1750 and any given decade would mean that the ranking and the differences in yields between the thirtythree provinces remained stable between both dates. The results for the two main grains (wheat and barley) indicate that it was not until the 1960s that the traditional structure of leaders and followers started to change. Even more striking is the fact that around 1950 structures were more similar to those of the mid- $18^{\text {th }}$ century than in the 1920 s. This fact could be related to the period of autarky in Spain that followed the end of the Second World War, and the policies that the regime adopted to become self-sufficient in the production of food ${ }^{18}$. The situation changed substantially through the 1950 s and by 1990 the correlations that marked the existence of a traditional regime had practically disappeared. The case of rye as an inferior grain was different, with the correlations with the yields of the mid- $18^{\text {th }}$ century remaining high until the

18 Prados explained the increase of the share of the primary sector in the Spanish economy during this period Prados (2008, p. 304). 
FIGURE 12

CORRELATION COEFFICIENT BETWEEN THE 33 PROVINCES WITH THE YIELDS

OF THE $1750 \mathrm{~S}$

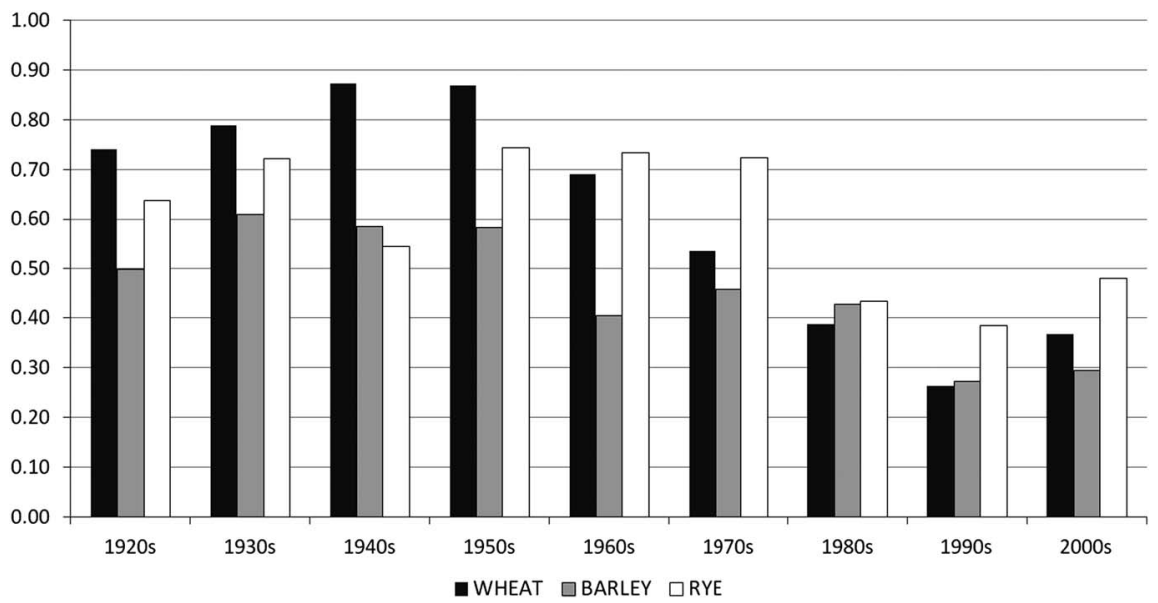

Source: 1750s calculated from the Catastro and INE (1920-2008) for the rest.

1970s when the modernisation process appears to have had a clear impact on the provincial differences. This situation is to be expected if we take into account the fact that the investments that changed the traditional structure probably took place earlier in the case of more profitable grains such as barley and, especially, wheat.

\section{FACTORS EXPLAINING REGIONAL VARIATION}

As presented in the first section of this study, the literature on agrarian history in Spain has highlighted geography and climate as important factors in order to explain the disadvantages faced by national producers, and also in the regional variability that we have presented. We have seen that it was in the north, where rainfall levels were similar to those in the rest of northwestern Europe, where Spanish producers were able to reap yields similar to those achieved in the most advanced agricultures of the continent and the world. A close study of the production systems in the provinces under our analysis also shows that in addition to the favorable climate regime, peasants in the northern provinces combined their harvests of grain with other crops like legumes, which helped to fix nutrients in the soil and therefore regenerated part of the fertility lost during the cultivation of cereals ${ }^{19}$. We should

\footnotetext{
19 For a detailed description of the fixation of nitrogen, see Allen (2008).
} 
also take into account that the relatively abundant rain in the north allowed the existence of a significant amount of livestock, which provided manure that could be used by grain producers as a natural fertiliser. However, not all natural conditions in the north were beneficial for the efficient production of grain. An important problem faced by producers in the north of Castile was the marginality of the terrain. The irregular landscape and the high percentage of marginal lands reduced the amount of soil that could be used in the production of high-quality grains such as wheat. The inhabitants of the north frequently complained about this situation; in the village of Amoedo in Galicia in the early 1750s they explained that «in this parish we do not cultivate wheat because the land is rough and hilly» ${ }^{20}$. We examined the proportion that the land used for grain production represented as a percentage of the total and, while in the provinces of Galicia the figure reached 20 per cent, in the rest of Castile values around 40 per cent and even higher were common ${ }^{21}$. This could also explain the reasons why, although similar to the average yields in countries such as England, the differences between yields in the most productive regions of Spain and the most productive in countries in north-western Europe were still large (Figure 11). In fact, although there was more livestock in the north of Spain than in the south, some authors argue that it was still not enough to produce the large amounts of organic fertiliser required in four-course systems (Gonzalez de Molina 2001, p. 64). In addition to the irregular landscape, land property in the north of Spain was characterised by very small farms, a situation that encouraged the development of subsistence instead of market economies characterised by low capital levels (Simpson 1992, p. 104).

On the other hand, the rest of the country, known as the «dry Spain», did not enjoy the same favorable climatic conditions for the cultivation of grain. The situation was particularly hard in the provinces of the south-east where rainfall levels could be up to twenty times lower than those in the north of the country. The lack of rain also meant that the possibilities to maintain and feed animals that could provide manure were far more limited, as was therefore the availability of manure to replenish the nutrients of the land and the cultivation of products like legumes that could replenish nutrients. In contrast to the situation in the northern provinces, the terrain in the rest of Spain was less irregular, especially in the provinces of the interior where the domination of the two plateaus imposed a flatter landscape. Property was also structured in a very different way, with larger producers who controlled huge agrarian exploitations in the south of the country.

Therefore, the provinces in the north, which enjoyed climatic conditions for the cultivation of grain as good as those in north-western Europe, were able to maintain an important number of animals, which provided manure

\footnotetext{
${ }^{20}$ Responses to question 12 of the village of Amoedo to the Catastro.

21 Calculations from the books of the Catastro.
} 
as a natural fertiliser, and also to a certain extent practised rotations in the cultivation of grain introducing products such as legumes that helped to replenish nutrients in the soil. However, the quality of the soil only allowed a small percentage of the land to be cultivated and the geography of the terrain worked against the introduction of mechanisation, while small farms developed undercapitalised subsistence economies that kept down labour productivity. The terrain in the south of Castile was more favourable than in the north, with a lower percentage of wasteland and forest. Land was also more concentrated in the hands of fewer producers who owned huge latifundia. Therefore, in principle, the south of Spain was more suitable for the emergence of large-scale properties like those that appeared in $18^{\text {th }}$ century England increasing labour productivity. However, the level of rain in large parts of the interior, the south and especially the south-east was considerably lower than in the north, a fact that for the reasons explained above, limited the average yields that could be reaped.

Spanish producers could have taken advantage of demand side factors that improved agricultural productivity in north-western Europe during the $18^{\text {th }}$ and $19^{\text {th }}$ centuries $^{22}$. Urban demand provided enough economic incentives for farmers to increase their production by improving productivity. Could demand forces explain the provincial variation within Spain? A recent paper argues that this was not the case. The econometric results suggest that demand forces like economic integration, population density or market potential did not play a significant role in the explanation of the differences in wheat yields across Spain. On the other hand, natural factors such as rain, altitude or roughness of the terrain were statistically significant (Santiago-Caballero forthcoming).

Counterfactual exercises show that natural endowments were not just statistically significant, but also relevant in economic terms explaining the differences in wheat yields in Spain and the low average level for the whole country. For example, had all the provinces analysed in this study enjoyed rainfall levels similar to those in the north, the average yield for the whole sample would have increased by 45 per cent. Furthermore, a combination of the best natural conditions that existed in the different provinces of our sample would have increased the average yield of the country by 141 per cent, to levels similar to the best performing regions of north-western Europe (Santiago-Caballero forthcoming). On the other hand, the study also suggests that even if Spain had enjoyed better natural conditions, institutional forces related to the unequal distribution of land and high transport costs within the country would have worked against increasing production at the intensive margin ${ }^{23}$.

22 See Postel-Vinay (1991), Wrigley (1985) or Kopsidis and Wolf (2012).

23 The availability of land and its unequal distribution encouraged producers to increase output at the extensive margin. Some studies still define large areas of Spain as frontier economies (Alvarez-Nogal and Prados de la Escosura, 2013). 


\section{CONCLUSIONS}

Wheat yields have been a familiar meeting point for the studies of agrarian historians in preindustrial times. There is a wide range of publications concerning the evolution of wheat yields in north-western Europe and also on the regional variance within countries such as France. However, the knowledge that we have of the evolution and heterogeneity of wheat yields in Spain is not as abundant as in other parts of Europe. We believe our study represents a new contribution to the existing literature on agricultural productivity with the creation of a dataset of grain yields in mid- $18^{\text {th }}$ century Spain at provincial level. Our results for mid- $18^{\text {th }}$ century Spain show a clear geographical pattern, with the provinces in the north obtaining yields three times higher than the average grain yields in the south-east of the country.

At first sight, the study of grain yields in mid- $18^{\text {th }}$ century Spain and the comparison with north-western Europe reveal the existence of an agricultural system that fell behind the most advanced countries in the continent. However, Spanish yields were not so far behind the yields achieved in southern Europe or other parts of the world. In fact, the provinces in the north-west of Spain were able to reap yields close to those obtained in some of the most advanced agrarian regions in the world.

The heterogeneity of wheat yields across Spain is explained by the differences in natural endowments faced by the different provinces. Rainfall levels in the north made it possible to achieve higher yields than in the rest of the country, an effect supported by the abundance of livestock, which provided natural fertiliser and also by the rotation of the cultivation of cereals and legumes. The small average size of the agrarian exploitations and the high proportion of infertile lands worked against the possibilities that producers in the north had to implement large-scale agrarian systems like those created in other countries with high labour productivity levels such as England. The provinces in the interior and the south of Spain had to confront inferior rainfall levels that were significantly lower, especially in the provinces of the south-east. Therefore, although the landscape and the percentage of infertile land was lower than in the north, and the scale of the exploitations was larger, yields remained low as did the possibilities of grain producers. In other words, grain producers in Spain were trapped by natural endowments, and while those in the interior and the south had to face unfavourable climatic conditions, those in the north were negatively affected by geographical and institutional factors, which made the adoption of large-scale production difficult.

Demand side factors were a key force driving up agrarian productivity in most of north-western Europe, but they did not play the same role in the case of Spain. On the other hand, natural endowments such as rainfall, altitude or roughness of the terrain reveal themselves as the main explanatory variables 
of the heterogeneity of grain yields across Spain. Although all the provinces of Castile were able to increase their yields in the long term, provincial differences remained and even increased over time. It was not until the modernisation forces of the 1960s, when low-yield provinces were finally able to break their natural constraints and the traditional order changed for the first time in hundreds of years.

\section{REFERENCES}

Allen, R. C. (1988): «Inferring Yields from Probate Inventories». The Journal of Economic History 48, pp. 117125.

Allen, R. C. (1992): Enclosure and the Yeoman. Oxford: Clarendon Press.

Allen, R. C. (2003): «Progress and Poverty in Early Modern Europe». The Economic History Review LVI, 3, pp. 403443.

Allen, R. C. (2004): «Agriculture During the Industrial Revolution», in R. Floud, and P. Johnson (eds), The Cambridge Economic History of Modern Britain. Volume I: industrialization, 1779 1860. Cambridge: Cambridge University Press, pp. 96116.

Allen, R. C. (2008): «The Nitrogen Hypothesis and the English Agricultural Revolution: A Biological Analysis». The Journal of Economic History 68, pp. 182210.

Allen, R. C. (2009): «Agricultural Productivity and Rural Incomes in England and the Yangtze Delta, c. 1620 c. $1820 »$. The Economic History Review 62, pp. 525550.

Allen, R. C., and O'Grada, C. (1988): "On the Road Again with Arthur Young». The Journal of Economic History 48, pp. 93116.

Alvarez Nogal, C., and Prados de la Escosura, L. (2013): "The Rise and Decline of Spain 1270 1850». Economic History Review 66 (1), pp. 137.

ANES, G. (1978): «La agricultura espanola desde comienzos del siglo XIX hasta 1868: algunos problemas», in J. Hernández Andreu (ed.), Historia Económica de España. Madrid: Editorial Ariel, pp. 235263.

Ayuda, M. I.; Collantes, F., and Pinilla, V. (2010): «From Locational Fundamentals to Increasing Returns: The Spatial Concentration of Population in Spain, 1787 2000». Journal of Geographical Systems 12 (1), pp. 2550.

Bejarano Rubio, A., and San Feliciano Lopez, M. L. (1999): «Producción y propiedad agrarias en la provincia de Salamanca a mediados del siglo XVIIIl. Los Estados Generales del Catastro de Ensenada». Salamanca: revista de estudios 42, pp. 405490.

Bringas Gutierrez, M. A. (2000): La Productividad de los Factores en la Agricultura Española (1752 1935). Madrid: Banco de Espana.

Calvo Alonso, C. (1999): «El catastro de Ensenada como fuente para el estudio de las fuerzas productivas locales a mediados del siglo XVIII», in P. Vilar, and C. Martinez Shaw (eds), Historia moderna, historia en construcción. Barcelona: Editorial Milenio, vol. 2, pp. 413426.

Camarero Bullon, C. (2002): "Averiguarlo todo de todos. El catastro de la Ensenada». Estudios Geograficos 63, pp. 248 249, 493532.

Chorley, G. P. H. (1981): «The Agricultural Revolution in Northern Europe, 1750 1880: Nitrogen, Legumes, and Crop Productivity». The Economic History Review 34, pp. 7193.

Clar, E., and Pinilla, V. (2009): «The Contribution of Agriculture to Spanish Economic Development», in P. Lains, and V. Pinilla (eds), Agriculture and Economic Development in Europe since 1870. London: Routledge, pp. 311332. 
Clark, G. (1991): "Yields per acre in English Agriculture, 1250 1860: Evidence from Labour Inputs». The Economic History Review 3, pp. 445460.

Clout, H. (1980): Agriculture in France on the Eve of the Railway Age. London: Barnes \& Noble Books.

De la Torre Briceño, A. (1992): «La producción agrícola en Arganda en el siglo XVIII, y su relación con los vecinos, colegios y conventos de Alcalá de Henares a través del Catastro de Ensenada». Anales Complutenses 4 5, pp. 207239.

Dejoongh, G. (1999): «New Estimates of Land Productivity in Belgium, 1750 1850». The Agricultural History Review 47, pp. 728.

Dobado Gonzalez, R. (2004): «Un legado peculiar: la geografía», in E. Llopis (ed.), El Legado Económico del Antiguo Régimen en España. Barcelona: Critica, pp. 97120.

Donezar Diez de Ulzurrun, J. M. (1984): Riqueza y propiedad en la Castilla del Antiguo Régimen. La provincia de Toledo en el siglo XVIII. Madrid: Instituto de Estudios Agrarios, Pesqueros y Alimentarios.

Fraile Balbin, P. (1991): Industrialización y Grupos de Presión: la Economía Política de la Protección en España, 1900 1950. Madrid: Alianza Editorial.

Fischer, G.; Velthuizen, H.; Shah, M., and Nachtergaele, F. (2002): Global Agro ecological Assessment for Agriculture in the 21st Century: Methodology and Results. Laxenburg: IIASA.

Gallego, D. (2001): "Crecimiento agrario, atraso y marco institucional», in J. Pujol et al. (eds), El Pozo de Todos los Males. Sobre el Atraso en la Agricultura Española Contemporánea. Barcelona: Critica, pp. 215239.

GaRcia SANZ, A. (1982): «La producción de cereales y leguminosas en Castilla la Vieja. Los diezmos del Obispado de Segovia de 1570 a 1800», in J. Goy, and E. Le Roy Ladurie (eds), Prestations Paysannes, Dîmes, Rente Foncière et Mouvements de la Production Agricole à l'époque Pré industrielle. Paris: Mouton, pp. 369383.

Garcia Sanz, A. (1986): Desarrollo y crisis del Antiguo Régimen en Castilla la Vieja. Economía y sociedad en tierras de Segovia de 1500 a 1814. Madrid: Akal.

Garrabou Segura, R. (1993): «Revolución o revoluciones agrarias en el siglo XIX: su difusión en el mundo mediterráneo», in A. Sanchez Picón (eds), Agriculturas mediterráneas y mundo campesino: cambios históricos y retos actuales : actas de las Jornadas de Historia Agraria. Almería, pp. 19 23. de abril de, 95109.

Gonzalez Castaño, J. (2009): Breve Historia de la Región de Murcia. Murcia: Tres Fronteras Ediciones.

Gonzalez de Molina, M. (2001): «Condicionamientos ambientales del crecimiento agrario espanol (siglos XIX y XX)», in J. Pujol et al. (eds), El Pozo de Todos los Males. Sobre el Atraso en la Agricultura Española Contemporánea. Barcelona: Critica, pp. 4393.

Goy, J., and Le Roy Ladurie, E. (1982): Prestations Paysannes, Dîmes, Rente Foncière et Mouvements de la Production Agricole à l'époque Pré industrielle. Paris: Mouton.

Grupo '75 (1977): La «Renta Nacional» de la Corona de Castilla. Madrid: Universidad Autónoma de Madrid.

Hoffman, P. T. (1988): «Institutions and Agriculture in Old Regime France». Politics and Society 16, pp. 241264.

INE, 1920 2008: Anuario Estadístico de España, Madrid: INE.

Kopsidis, M., and Wolf, N. (2012): «Agricultural Productivity across Prussia during the Industrial Revolution: A Thunen Perspective». Journal of Economic History 72, pp. 634670 .

Lanza Garcia, R. (2008): «Producto neto, gasto y crecimiento económico en el Antiguo Regimen: el caso de Cantabria». Paper presented at the IX Congreso Internacional de la Asociación Espanola de Historia Económica, Murcia, September 912. 
LEMEunier, G. (1997): «Drenaje y crecimiento agrícola en la Espana mediterránea (1500 1800)». Áreas: Revista de Ciencias Sociales 17, pp. 3141.

Llopis, E. (2002): «Expansión, reformismo y obstáculos al crecimiento (1715 1789)», in F. Comin, M. Hernandez, and E. Llopis (eds), Historia Económica de España Siglos $X X X$. Barcelona: Editorial Crítica, pp. 121164.

Lopez Salazar Perez, J., and Martin Galan, M. M. (1981): «La producción cerealista en el arzobispado de Toledo: 1463 1699». Cuadernos de historia moderna y contemporánea 2, pp. 21104.

Matilla Tascon, A. (1947): La Única Contribución y el Catastro de la Ensenada. Madrid: Ministerio de Hacienda.

Mironov, B., and A'Hearn, B. (2008): «Russian Living Standards under the Tsars: Anthropometric Evidence from the Volga». Journal of Economic History 68, pp. 900929.

Mula Gomez, A., and Gris Martinez, J. (1998): «El interrogatorio de 1755. Aproximación a la estructura productiva de Lorca a mediados del siglo XVIII». Contrastes. Revista de Historia Moderna pp. 3 4, 2752.

Muñoz Navarro, D. (2010): «El Catastro de Ensenada como fuente para la Historia Agraria: paisaje y actividad agropecuaria en la villa de Requena a mediados dl siglo XVIII». CT: Catastro 70, pp. 5169.

NADAL, J. (1984): El Fracaso de la Revolución Industrial en España, 1814 1913. Barcelona: Ariel.

O'Brien, P. K., and Keyder, C. (1978): Economic Growth in Britain and France, 1780 1914: Two Paths to the Twentieth Century. London: George Allen and Unwin.

O'Brien, P. K., and Prados de la Escosura, L. (1992): «Agricultural Productivity and European Industrialization, 1890 1980». The Economic History Review 45 (3), pp. 514536.

Overton, M. (1979): «Estimating Crop Yields from Probate Inventories: An Example from East Anglia, 1585 1735». The Journal of Economic History 39, pp. 363378 .

Overton, M. (1990): «Re estimating Crop Yields from Probate Inventories: A Comment». The Journal of Economic History 39, pp. 363378.

Pezzi Cristobal, P. (1997): «Producción y rendimientos agrarios en Vélez Málaga según el catastro». Baética: Estudios de arte, geografía e historia 19 (2), pp. 149160.

Prados de la Escosura, L. (1988): De imperio a Nación. Crecimiento y Atraso Económico en España (1780 1930). Madrid: Alianza Editorial.

Prados de la Escosura, L. (2008): «Inequality, Poverty, and the Kuznets Curve in Spain, 1850 2000». European Review of Economic History 12, pp. 287324.

Ponsot, P. (1986): Atlas de Historia Económica de la Baja Andalucía (Siglos XVI XIX). Sevilla: Editoriales Andaluzas Unidas.

Ringrose, D. R. (1983): Madrid and the Spanish Economy. Berkeley: University of California Press.

Santiago Caballero, C. (2011): «Income Inequality in Central Spain 1690 1800». Explorations in Economic History 48 pp. 8396.

SANTIAGo Caballero, C. (2013): "Inequality and Agrarian per capita Income in Central Spain: Guadalajara 1690 1800», in P. Svensson, and E. Hillbom (eds), Agricultural Transformation in a Global History Perspective. London: Routledge, pp. 160183.

Santiago Caballero, C. (forthcoming): «Explaining Wheat Yields in Eighteenth Century Spain», European Review of Economic History. 
Santiago Caballero, C. (forthcoming): Tithe Series and Grain Production in Central Spain (1700 1800) Rural History.

Simpson, J. (1992): "Los límites del crecimiento agrario: Espana, 1860 1936», in L. Prados de la Escosura and V. Zamagni (eds), El Desarrollo Económico en la Europa del Sur: España e Italia en Perspectiva Comparada. Madrid: Alianza Editorial, pp. 103138.

Simpson, J. (1997): Spanish Agriculture: the Long Siesta, 1765 1965. Cambridge: Cambridge University Press.

Tortella, G. (1994): «Patterns of Economic Retardation and Recovery in South Western Europe in the Nineteenth and Twentieth centuries». The Economic History Review 47 (1), pp. 121.

Tortella, G. (2003): El Desarrollo de la España Contemporánea. Historia Económica de los Siglos XIX y XX. Madrid: Alianza Editorial.

TuRner, M. (1982): «Agricultural Productivity in England in the Eighteenth Century: Evidence from Crop Yields». The Economic History Review 35, pp. 489510

VILAR, P. (1966): «Structures de la société espagnole vers 1750. Quelques leçons du cadastre de La Ensenada», in J. Sarrailh (ed.), Mélanges à la mémoire de Jean Sarrailh. París: Institut d'Études Hispaniques, pp. 425447.

Wrigley, E. A. (1985): "Urban Growth and Agricultural Change: England and the Continent in the Early Modern Period». Journal of Interdisciplinary History 15, pp. 638728 .

\section{APPENDIX}

\section{Methodological notes:}

The average yield for Spain was calculated as a weighted average of the provincial yields, using the land dedicated to the cultivation of grain in each province as weight. We obtained the land used for grain production in each province from the 1858 statistical bulletin, the first available source to use the modern boundaries.

\section{Units of measurements used in the paper:}

\section{Surface}

- Día de Bueyes: used in the north of Spain, especially in Asturias.

- Ferrado: used in the north of Spain, especially in Galicia.

- Fanega: the most common measurement used in Castile.

- Obrada: in some areas equivalent to the fanega, although it changes in other places.

- Estadal: the value changed depending on the region, although it was normally around 16 square varas.

- Carro de tierra o heredad: mostly used in Cantabria.

- Fanega de puño: found mainly in the provinces of the interior. However, it was highly irregular as it was measured as the amount of land that was occupied after seeding one fanega (capacity) of grain. 


\section{Length}

- Vara Castellana: $0.838 \mathrm{~m}$.

- Paso: 1 vara castellana.

- Pie: 3 pies made 1 vara castellana.

- Palmo: 4 palmos made 1 vara castellana.

\section{Dry Volume}

- Fanega: 55.51.

- Ferrado: normally used in the north. The value depended on the region.

- Maxal: found in Granada had 3 celemines.

- Celemín: 12 celemines $=1$ fanega.

- Cahiz: 1 Cahiz $=12$ fanegas.

- Almud: 2 almudes $=1$ fanega.

- Carga: normally 4 fanegas.

- Cuartal: in some areas of the north equivalent to the ferrado.

- Tega: found in areas like Zamora. Normally 3 celemines.

- Hemina: 1 fanega $=3$ heminas. 